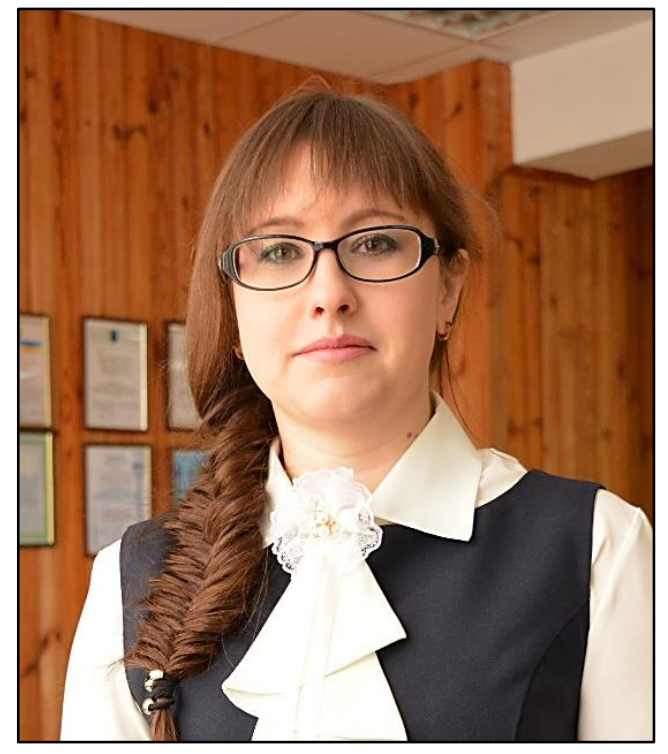

\section{HRYSHCHENKO}

Tetiana R.,

Ph.D. in History,

Senior Research Fellow, Head of the Archives Sector

Institute of the History of Agrarian Science,

Education and Techniques,

National Scientific Agricultural Library of the National Academy of Agrarian Sciences of Ukraine,

e-mail: tatdnsgb@ukr.net

(Kyiv city, Ukraine)

\title{
THE CONTRIBUTION OF THE
}

\section{AGRICULTURAL SCIENTIFIC COMMITTEE OF UKRAINE (1918-1927) \\ IN THE SCIENTIFIC AND ORGANIZATIONAL SUPPORT OF THE AGRARIAN SCIENCE DEVELOPMENT}

The historical research is about the role and place of the predecessor of the National Academy of Agrarian Sciences of Ukraine - Agricultural Scientific Committee of Ukraine (1918-1927) in the scientific and organizational support of the development of the domestic agrarian science and experimental case. The author carried out the historical exploration using general scientific methods: analysis, synthesis, classification and historical methods: historical research, problemchronological, comparative-historical, periodization and retrospective. She observed the evolutionary way of the Committee's activity and paid attention on the main achievements in different directions. The significant role had its international and publishing activities. An important place in the deeds of the NAAS successor allotted the successfully organized high-level scientific and methodical work of its regional offices. The Network of Correspondents of the Agricultural Scientific Committee of Ukraine played an essential role in the formation and development of the national economy of Ukraine in the 20's the last century. It is encouraging to note that the Ukrainian National Memory Institute confirmed the results of our historical exploration on the date of NAAS establishment. This decision described the noteworthy contribution of the Committee to the development of agrarian science and research case in the defined period.

Keywords: Agricultural Scientific Committee of Ukraine, National Academy of Agrarian Sciences of Ukraine, National Scientific Agricultural Library, Institute of the 
History of Agrarian Science, Education and Techniques, agricultural science, research case, support, contribution.

\section{ВНЕСОК СІЛЬСЬКОГОСПОДАРСЬКОГО НАУКОВОГО КОМІТЕТУ УКРАЇНИ (1918-1927) У НАУКОВО-ОРГАНІЗАЦІЙНЕ ЗАБЕЗПЕЧЕННЯ РОЗВИТКУ АГРАРНОЇ НАУКИ}

Історична розвідка присвячена визначенню ролі та місия предтечі Національної академії аграрних науки України - Сільськогосподарського наукового комітету Украӥни (1918-1927) у науково-організачійному забезпеченні вітчизняної аграрної науки та дослідної справи. У дослідженні автор застосувала загальнонаукові методи: аналізу, синтезу, класифікації та історичні - історико-науковий аналіз, проблемно-хронологічний, порівняльний, періодизачї та ретроспективний. Дослідниия окреслила еволюиійний поступ діяльності Комітету $і$ зосередила увагу на його головних здобутках у різних напрямах. Вагому роль у науково-організаційному забезпеченні аграрної галузі відіграли міжнародна і видавнича складові. Важливе місие у творчому доробку попередника НААН посідала вдало організована на високому рівні науковометодична робота регіональних представництв. Значний внесок у становлення й розвиток національної економіки Украӥни у 20-х роках минулого століття зробила Сітка кореспондентів Сільськогосподарського наукового комітету України. Відрадно зазначити, щуо наші історичні пошуки щодо дати заснування Національної академії аграрних наук Украӥни були підтверджені резолючією Украйнського інституту національної пам'яті. Відтак, беззаперечним $i$ визнаним є внесок Комітету у розвиток аграрної науки та дослідної справи у визначений період.

Ключові слова: Сільськогосподарський науковий комітет Украйни, Національна академія аграрних наук України, Національна наукова сільськогосподарська бібліотека, Інститут історії аграрної науки, освіти та техніки, аграрна наука, дослідна справа, забезпечення, внесок.

\section{ВКЛАД СЕЛЬСКОХОЗЯЙСТВЕННОГО НАУЧНОГО КОМИТЕТА УКРАИНЫ (1918-1927) В НАУЧНО-ОРГАНИЗАЦИОННОЕ ОБЕСПЕЧЕНИЕ РАЗВИТИЯ АГРАРНОЙ НАУКИ}

Проведенное историческое исследование посвящено определению роли и места предшественника Национальной академии аграрных наук Украины Сельскохозяйственного научного комитета Украины (1918-1927) в научноорганизационном обеспечении отечественной аграрной науки и опытного дела. Автор применила общенаучные методы исследования: анализ, синтез, классификаиия и исторические - историко-научный анализ, проблемнохронологический, сравнительный, периодизащии и ретроспективныій. Исследовательница раскрыла эволюиионное развитие деятельности Комитета 
u сосредоточила свое внимание на его главных достижениях в разных направлениях. Важную роль в научно-организационном обеспечении аграрной отрасли занимали международная и издательская деятельность учреждения. Большое значение в творческом наследии предшественника Начиональной академии аграрных наук Украины имела прекрасно организованная на высоком научно-методическом уровне работа региональных представительств. Существенный вклад в становление и развитие национальной экономики Украины в 20-х годах прошлого века внесла Сетка корреспондентов Сельскохозяйственного научного комитета Украины. Приятно отметить, что наши исторические почски относительно даты создания Национальной академии аграрных наук Украины были подтверждены резолюиией Украинского института национальной памяти. Таким образом, безоговорочным и признанным является вклад Комитета в развитие аграрной науки и опытного дела в указанный период.

Ключевые слова: Сельскохозяйственный научный комитет Украины, Наџиональная академия аграрных наук Украины, Наџиональная научная сельскохозяйственная библиотека, Институт истории аграрной науки, образования и техники, аграрная наука, опытное дело, обеспечение, вклад.

In 2018, the National Academy of Agrarian Sciences of Ukraine celebrates 100 years. The scientists of the Institute of the History of Agrarian Science, Education and Techniques of the National Scientific Agricultural Library of the National Academy of Agrarian Sciences of Ukraine interested in question: what was essentially its formation and where does it keep track of it? Our many years of historical research concluded, that the forerunner of the NAAS was the Agricultural Scientific Committee of Ukraine, which functioned during 1918-1927.

The purpose of the article is to reveal the contribution of the Committee to the scientific and organizational provision of the development of the agrarian sector. The author used such methods as: a) the general scientific: analysis, synthesis, classification and b) the historical: problem-chronological, comparative-historical, retrospective and periodization.

The evolutionary progress of sectoral research on Ukrainian lands was difficult and quite controversial. In different periods, the search for optimal organizational structures aimed at adapting to existing conditions, applied the latest approaches, and implemented the best from foreign experience etc. Until 1917, there was no coordination branch center on Ukrainian lands [1]. The significant changes began with 
the establishment in Kiev in late 1917 the Office of Land Affairs that changed its name and forms of activity under different power systems. I would like to notice that so far there was no own organizational model of agrarian science, and decided to take a sample of the Russian model. It has been successfully functioning since 1837 as Scientific Committee - an advisory body of the Ministry of Public Property of the Russian Empire. Finally, November 1, 1918 the Ukrainian State Ministry of Land Affairs established the Scientific Committee. The academician Volodymyr I. Vernadsky became its first head [2]. The formation of modern NAAS began just from this time.

During the entire period of its activity, the official names changed three times:

1) Scientific Committee of the Ministry of Land Affairs (November 1, 1918);

2) Agricultural Scholarly Committee of Ukraine (May 19, 1919);

3) Agricultural Scientific Committee of Ukraine (November 25, 1920).

Depending on the problems and needs through improved and expanded organizational structure of the Committee. According to the Charter of 1919, the appointment of the heads changed to the election, implemented ranks: Member, Corresponding Member and Associate Members. There are vacancies of honorary members. For the most outstanding scientific achievements in certain branches of agricultural sciences, the Committee appointed a senior doctor's degree. There was training of scientific personnel. The Committee founded different institutes of staff members, correspondents, scholars, practitioners, as well as corresponding courses, seminars, contests of scientific works.

In 1920, all agricultural research institutions of Kyiv and Kyiv region joined the Committee: South Russian Society of Agriculture and Agricultural Industry; AllRussian Sugar Producers Society; Kiev Society of Agronomy; Kyiv Society of Agriculture and Agricultural Industry; Kyiv Provincial Zemstvo; Central Agricultural Cooperative Union «Central» etc.

The apogee of scientific and organizational support for the development of agrarian science became 1923. The Committee succeeded in starting institutionalization. It launched at 17 its sections separate problem institutes and 
bureaus, which became the forerunner of modern scientific centers of NAAS. Among them were: the Institute of Breeding; the Institute of Seed Science; the Institute of Experimental Soil Science; the Agricultural Synoptic and Conjuncture Institute; the Institute of Agricultural Chemistry; the Central Phytopathological Station; the Central Entomology Station; the Central Station for Research of Forage Plants; the Central Fishing Station; the Fisheries Bureau; the Central Station for Agricultural Meteorology; the Central Meteorological Radio Station; the Central laboratory for Meteorological Checking; the Workshop of the Exact Product; the Meteorological Museum; the Central Agricultural Museum; the Central Agricultural Library etc.

There were 11 representative of the Committee in Ukraine: Podilsk (Vinnitsa and Kamenets-Podolsk), Volyn, Uman, Kiev, Odessa, Poltava, Lubny, Zhytomyr, and Ekaterinoslav and the Bureau of the Agricultural Scientific Committee of Ukraine at the Ukrainian SSR People's Commissariat of Land Affairs in Kharkiv. It is worth noting that such a unique phenomenon in the agrarian sector, as a correspondent network, is a vivid example of a public initiative in the development of sectoral research [3].

In different years, at the head of the Committee were brilliant organizers of science, prominent scholars: Academician Volodymyr I. Vernadsky (1918); Professor Borys G. Ivanitsky (1918); Academician Pavlo A. Tutkovsky (1919); Professor Solomon L. Frankfurt (1919-1921), Professor Sergei F. Veselovsky (1922-1923); Volodymyr I. Kovalevsky (1923-1924), acted as chairman of the committee - Irynarh M. Shchoholiv (1923) and Pavlo F. Tushkan (1924); Moses M. Wolf (1924-1926) and Professor Oleksiy N. Sokolovsky (1926-1927). Precisely because of their intellectual efforts in the 1920's the Ukrainian society began a purposeful awakening of scientific consciousness, and consequently, the gradual establishment of agrarian science as an independent area of knowledge and organization.

An interesting fact in the history of NAAS is that the shelter of his forerunner provided the consistory of Sophia of Kyiv in the second half of 1919. Thus, in difficult times the church supported agrarian science. 
Having swept through economic and socio-political thorns, the Committee became the main coordinating, scientific-methodical center of agrarian science and education in Ukraine. It was responsible for the comprehensive development of agricultural museums and libraries of all departments and organizations. Among its outstanding achievements are the following:

$\checkmark$ Creation of the first synthetic map of Ukrainian soils and publication «Матеріали дослідження грунтів України» («The Materials of Ukrainian Soil Research») in 10 volumes;

$\checkmark$ Publication of the first textbook in Ukrainian «Грунтознавство» («Soil Science»);

Making for the first time in the history of Ukraine 25-verst maps: soils, hypsometric and quaternary geological deposits;

$\checkmark$ Organization of the Unified Hydrometeorological Service of Ukraine UKRMET;

$\checkmark$ Creation of the first unique botanical-geographical map of the Ukrainian SSR and the Ukrainian botanical classification;

$\checkmark$ Complex study of the features of drought-resistant plants and weeds; flies of meadows and swamps;

$\checkmark$ Elaboration of economically grounded technological bases of production, processing and export of technical, oilseeds and grain crops in the Ukrainian SSR;

$\checkmark$ Development of economically grounded methodology of regionalization of the Ukrainian SSR or specialization of agriculture in the natural-climatic zones;

$\checkmark$ Introduction of a new economic policy in the USSR for six months earlier than the RSFRR, and the planning in the work of all the commissariats of the republic;

$\checkmark$ Comprehensive study of the problems of the Ukrainian agricultural market, wage rates, etc.;

$\checkmark$ A number of draft laws on nature conservation and forestry, in particular the nationalization of the Askaniya-Nova and Koncha Zaspa reserves; the creation of the «Antonina» fish reserve, the T.G. Shevchenko State Forest-Steppe Reserve and others. 
Development and wide introduction in Ukraine of its own decimal classification of literature in compliance with international bibliographic norms, etc.

The Committee conducted extensive international cooperation with more than 300 foreign scientific institutions and held a fruitful exchange of experience, literature, knowledge and achievements at both the theoretical development and in the plane of implementation [4]. For the first time in the «Statute of the Agricultural Scientific Committee of Ukraine» dated November 25, 1920 indicated about the international activity: «In order to most intensive and comprehensive development of agricultural science in Ukraine at the level of its progress worldwide, the Committee connecting constant contact with all the relevant research institutions, as separate countries and organizations of an international character, and, on its part, is an international center of agricultural science and scientific experiments farming in all its manifestations» [5]. The document also identifies that the Committee collects and elaborates data on global state of agriculture and agricultural science in particular. In addition, it gained the right to organize their representation in relevant institutions in other countries and generally establish close cooperation. Thus in the structure of the Agricultural Scientific Committee of Ukraine appears Foreign Affairs Bureau. Its work led by J. Majewski with technical assistance of the Secretariat Organizational Department. Newly created Bureau actively joined to establish business relations with foreign countries, especially through special correspondence [6]. Consequently, the Committee began to work with agrarian organizations in England, Belgium, Italy, Germany, USA, France, Czechoslovakia, Sweden and others. Because of archival searches, we able to find a document adopted December 29, 1923 by the Plenary Assembly of the Agricultural Scientific Committee of Ukraine. It noted that the delegated «... representative of the Presidium has acquainted with the state of agricultural research work in Europe and America in particular - to establish contact between the Agricultural Scientific Committee of Ukraine and the International Institute of Agriculture in Rome» [7]. Thus, before the specialists raised the specific task of establishing international cooperation. The Committees' international activity took place on problematic issues, 
because the institution as a coordinating and leading scientific center of agricultural science trying to find solution to various problems of the domestic agriculture.

The publishing activity of the Committee was widely known in the country and abroad. Over 30 titles of periodicals edited [8]. In addition, it paid much attention to the study of the national agricultural life, the development of Ukrainian technical terminology and other.

Unfortunately, the next optimization processes eclipsed the prosperity of the Committee's work. As a result, the Committee on a broad public-governmental organization, which existed under the profile department on an autonomous basis, turned into its scientific-practical institution. Nevertheless, this did not stop. Moreover, in 1927, People's Commissar O.G. Schlichter initiated the liquidation of the Committee for nationalist manifestations, and its functions he transferred to the Scientific Advisory Board, which completely resembled its predecessor in the structure.

The conducted historical and scientific analysis of the formation and activity of the Agricultural Scientific Committee of Ukraine testified that the significant contribution of the construction of sectoral research on Ukrainian lands after the events of 1917 and scientific and organizational provision of the development of the agrarian sector belongs to the Committee. It was a peculiar phenomenon and corresponded to the essence of the modern academic scientific-coordinating institution, and the range of scientific research covering almost all branches of agricultural science, even ahead of the powerful scientific institutions that functioned after it.

It is encouraging to note that the Ukrainian National Memory Institute confirmed the results of our historical exploration on the date of NAAS establishment. It was supported by the NAAS Bureau and the Committee on Culture and Spirituality of Verkhovna Rada of Ukraine to include the 100th anniversary of NAAS to the draft resolution of the Verkhovna Rada of Ukraine «On awarding memory" date and anniversaries in 2018».

\section{List of Literature}


1. Грищенко Т. Р. Научно-организационные аспекты становления Сельскохозяйственного ученого комитета Украины. Молодой ученый. [Казань], 2015. № 24. C. 816-818.

2. Грищенко Т. Р. Академік В. Вернадський (1863-1945) - перший голова Сільськогосподарського вченого комітету України. Гілея : наук. вісн. Київ, 2013. № 76 (№ 9). C. 57-59.

3. Грищенко Т. Р. Сітка кореспондентів Сільськогосподарського наукового комітету України як приклад громадської ініціативи у розбудові галузевого дослідництва. Історія науки $i$ біографістика. 2016. № 2. URL : http://inb.dnsgb.com.ua/2016-2/hryshchenko.pdf (дата звернення : 22.12.2017).

4. Hryshchenko T. R. International activities of the Agricultural Scientific Committee of Ukraine. Proceedings of young scientists. [Baku], 2017. № 15. P. 95100.

5. Статут Сільсько-Господарського Наукового Комітету України. Бюлетень Сільськогосподарського наукового комітету Украӥни. Київ, 1921. № 1-3. С. 1012.

6. Коротке справоздання про діяльність Сільсько-Господарського Наукового Комітету України за 1923-1924 операц. рік. Вісн. с.-2. науки. [Харків], 1924. № 7-9. С. 73-102.

7. Короткий план діяльності Сільско-Господарського Наукового Комітету в 1924 році. Вісн. с.-г. науки. [Харків], 1924. № 1-2. С. 26-39.

8. Hryshchenko T. R. Branch periodical journals as the powerful informational source of scientifically-organizational activity of Agricultural Scientific Committee of Ukraine in 1918-1927. Науният потенциал на света - 2013 : матеріали за 9-а международна научна практична конференция (гр. София, Република България 17-25 септември 2013). София, 2013. Т. 7 : История. С. 52-55.

\section{References}

1. Hryshchenko, T. R. (2015). Nauchno-organizacionnye aspekty stanovlenija Sel'skohozjajstvennogo uchenogo komiteta Ukrainy [Scientific and organizational aspects of the formation of the Agricultural Scientific Committee of Ukraine]. Molodoj uchenyj [Young scientist]. Kazan. 24, 816-818. [in Russian].

2. Hryshchenko, T. R. (2013). Akademik V. Vernadsky (1863-1945) - pershyj golova Silskogospodarskogo vchenogo komitetu Ukrayiny [Academician V. Vernadsky (1863-1945) - the first chair of the Agricultural Scientific Committee of Ukraine]. Gileya : nauk. visn. [Gilea : Scientific Bulletin]. Kyiv. 76 (9), 57-59. [in Ukrainian].

3. Hryshchenko, T. R. (2016). Sitka korespondentiv Sil's'kohospodars'koho naukovoho komitetu Ukrayiny yak pryklad hromads'koyi initsiatyvy u rozbudovi haluzevoho doslidnytstva [The network of correspondents of Agricultural Scientific Committee of Ukraine as an example of public initiatives in the development of branch research case]. Istoriya nauky i biohrafistyka: elektronne naukove fakhove vydannya mizhvidomchyy tematychnyy zbirnyk [History of Science and Biographical Studies: electronic scientific professional edition - interdepartmental thematic collection]. 2, from http://inb.dnsgb.com.ua/2016-2/hryshchenko.pdf. [in Ukrainian]. 
4. Hryshchenko, T. R. (2017). International activities of the Agricultural Scientific Committee of Ukraine. Proceedings of young scientists. Baku. 15, 95-100. [in English].

5. Statut Sil's'ko-Hospodars'koho Naukovoho Komytetu Ukrayiny. (1921). [The Charter of the Agricultural Scientific Committee for Ukraine]. Byuleten' Sil's'koHospodars'koho Naukovoho Komytetu Ukrayiny [Bulletin of the Agricultural Scientific Committee of Ukraine], Kyiv. 1-3, 10-12. [in Ukrainian].

6. Korotke spravozdannya pro diyal'nist' Cil's'ko-Hospodars'koho Naukovoho Komitetu Ukrayiny za 1923-1924 operats. rik. (1924). [A brief report on the activities of the Agricultural Scientific Committee of Ukraine for 1923-1924 operations. year.]. Visnyk sil's'kohospodars'koyi nauky [Journal of Agricultural Science]. 7-9, 73-102. [in Ukrainian].

7. Korotkyy plan diyal'nosti Sil's'ko-Hospodars'koho Naukovoho Komitetu v 1924 rotsi. (1924). [A brief outline of Agricultural Scientific Committee in 1924]. Visnyk sil's'kohospodars'koyi nauky [Journal of Agricultural Science]. 1-2, 26-39. [in Ukrainian].

8. Hryshchenko, T. R. (2013). Branch periodical journals as the powerful informational source of scientifically-organizational activity of Agricultural Scientific Committee of Ukraine in 1918-1927. NauniJat potencial na sveta-2013 : materiali za 9-a mezhdunarodna nauchna praktichna konferenciJa (gr. SofiJa, Republika B"lgariJa 17-25 septemvri 2013) [World Scientific Potential -2013: the material for the ninth international scientific practical conference (Sofia, Republic of Bulgaria 17-25 September 2013). Sofia, 7, 52-55. [in English].

\section{Reviewer:}

Irina Borodai, Doctor of History, Professor

Received 19/12/2017 